УДК 338.22

\title{
РОЛЬ ІНФОРМАЦІЙНО-КОМУНІКАЦІЙНОГО СЕКТОРУ В РОЗВИТКУ НАЦІОНАЛЬНОÏ ЕКОНОМІКИ
}

\section{THE ROLE OF INFORMATION AND COMMUNICATION SECTOR IN THE DEVELOPMENT OF THE NATIONAL ECONOMY}

\author{
Васильків Богдан Любомирович \\ аспірант, \\ Львівський національний університет імені Івана Франка \\ ORCID: https://orcid.org/0000-0003-4469-8239 \\ Vasylkiv Bohdan \\ Ivan Franko National University of Lviv
}

\begin{abstract}
У статті розглянуто особливості впливу сектору інфоормаційно-комунікаційних технологій на національну економіку. Проаналізовано головні тенденції використання інформаційно-комунікаційних технологій за видами економічної діяльності в Україні та динаміку інвестування у цей сектор. Визначено важливість сектору інсрормаційно-комунікаційних технологій для досягнення прогресивних змін в національній економіці. Специфріковано рівні регулювання сектору інсрормаційно-комунікаційних технологій в Україні та за кордоном. Встановлено, що за умови впроваджень ефективних рішень щодо подальшого розвитку сектору інформаційнокомунікаційних технологій Україна зможе підвищити рівень конкурентоспроможності на світовому ринку.

Ключові слова: інформаційно-комунікаційні технології, економіка, розвиток, тенденції, регулювання.
\end{abstract}

В статье рассмотрены вопросы сущности инфрормационно-коммуникационных технологий. Рассмотрены инорормационно-коммуникационные технологии в разрезе отдельных подходов. Проанализированы статистические дни по использованию инсормационно-коммуникационных технологий на предприятиях Украины и обеспечения работниками исследуемой сферы за последние года. Определена роль информационно-коммуникационного сектора в развитии экономики в условиях современного состояния. Показано уровни регулирования инорормационно-коммуникационного сектора в международных данных и положение Украины в них. Установлено, что при внедрений эсрфективных решений по дальнейшему развитию информационнокоммуникационного сектора Украины сможет повысить уровень конкурентоспособности на мировом рынке.

Ключевые слова: информационно-коммуникационные технологии, экономика, развитие, тенденции, регулирование.

The article considers the role of information and communication technologies in the development of the national economy. In the current conditions of globalization transformations and the formation of the digital world, the economy and Ukrainian society are significantly affected by information technology, which is reflected in all areas of modern enterprises, both commercial and government. Information and communication technologies are defined as a set of various technological tools and resources used to support the communication process and the creation, dissemination, storage and management of information. Statistical days on the use of information and communication technologies at Ukrainian enterprises and the provision of employees in the study area are analyzed. Also, in recent years, it is determined that the largest part of employees is in the processing industry, trends in investing in computer programming and other information services have a positive trend. The article emphasizes the importance of information and communication technologies in education, business and the public sector. Among the areas of improvement of the education sector is the need to increase the cooperation of higher education institutions with the business sector to implement effective teaching methods. It is determined that most enterprises both in Ukraine and in the world in general build internal processes using information technology and automation processes. In business, the role of information and communication technologies is reflected in the automation of both internal and external processes, simplification of processing large amounts of data and systematization of necessary processes in enterprises. As a result, it was concluded that to improve the state of the information and communication sector in the national economy, Ukraine should develop a domestic information market to reduce dependence on exports and strengthen the stability of economic development, strong domestic competition will intensify the activity of information market subjects.

Keywords: information and communication technologies, economy, development, tendencies, regulation. 
Постановка проблеми. Одним із видів економічної діяльності, що інтенсивно розвивається і впливає на конкурентоспроможність національної економіки $€$ сектор інформаційно-комунікаційних технологій (IKT). Глобальні перетворення на основі використання IKT поширюються на всі ссрери та стають важливими чинниками розвитку як окремої країни, так і транснаціональних компаній. Перехід від індустріального до інформаційного суспільства відображається через економічне процвітання, стабільний соціальний розвиток і поліпшення стандартів життя населення. Завданнями активізації розвитку сектору IKT $€$ удосконалення інституційно-організаційного середовища його фрункціонування в національній економіці.

Аналіз останніх досліджень і публікацій. Теоретичні та прикладні дослідження, пов'язані з визначенням особливостей розвитку сектору IKT проведено такими українськими науковцями, як К.О. Безуглої, Л.М. Уніят стосовно його інноваційного аспекту, С.П. Карапиша в контексті освіти, І.П. Малика з позиції фрормування інфрормаційної економіки. Однак, з'ясування значення сектору IKT для розвитку національної економіки потребує детальнішого аналізу, оскільки цей сектор є динамічним та адаптивним до змін, інтегрованим у різні галузі національної економіки.

Формулювання цілей статті. Метою статті $€$ з'ясування значення сектору IKT для розвитку національної економіки України. Це дасть можливість ідентифрікувати головні напрями поліпшення його фрункціонування в українській економіці.

Виклад основного матеріалу дослідження. Еволюційно фрормування сектору IKT тісно пов'язане 3 переходом суспільства від індустріального до постіндустріального. Значення сектору IKT в економічному та соціальному житті країни зумовлене з його швидким зростанням у середині 1990-х рр. XX ст. У 1970-х рр. з'явилася мікропроцесорна технологія, яка дала змогу комп'ютеру стати персональним і доступним масовому споживачеві. Це змінило концептуальні положення інфрормації, бо виділилися її доступність інфрормації, швидкість та обсяг передавання, відбулося створення нових моделей та механізмів інсрормаційного впливу на суспільство і національну економіку.

Зміна інформаційного середовища спричинили транссрормацію багатьох соціально-економічних явищ: динамічне оновлення техніки і технологій, формування віртуального та цифр- рового просторів, автоматизація виробничих та комерційних процесів. Країни почали активно використовувати IKT для сталого розвитку та виокремлення творчих та інноваційних знань.

Дослідження поняття «ІКT» та їхнього значення у науковій літературі виявляється у трьох основних підходах: освіта (заклади вищої освіти, заклади середньої освіти), окреме підприємство, окремий сектор та економіка загалом. 3 огляду на це доцільно акцентувати увагу на важливості всіх складових, оскільки аналізуючи вплив IКТ на окремі сектори національної економіки можна виокремити особливості становлення та розвитку інфрормаційної економіки загалом.

IKT - це система інсрормаційних технологій та інтеграції телекомунікацій (телефронних ліній та бездротових з'єднань), комп'ютерів, програмного забезпечення, накопичувальних та аудіовізуальних систем, які дозволяють користувачам створювати, одержувати доступ, зберігати, передавати та змінювати інсрормацію [7, с. 152].

На думку авторів, ІКТ - це сукупність різноманітних технологічних інструментів і ресурсів, які використовуються для забезпечення процесу комунікації та створення, поширення, збереження та управління інфрормацією [5, с. 65].

При визначенні значення впровадження IKT у системі управління загальної середньої освіти С.П. Карапиш зазначив, що в управлінні якістю освіти застосування IКT визначається рядом чинників: сучасні IKT, підвищуючи якість навчання та освіти, дають змогу людині успішніше й швидше адаптуватися до навколишнього середовища, до соціальних змін; активне й ефективне впровадження цих технологій в освіту $є$ важливим чинником створення нової системи освіти, що відповідає вимогам процесу модернізації традиційної системи освіти [3, с. 40].

Досліджуючи питання сорер застосування IKT зафріксовано найбільшу кількість фрахівців цього сектору у переробній промисловості, торгівлі і ремонту автотранспортних засобів. Вважаємо, що дана ситуація пов'язана з тим, що в більшості підприємствах цих видів економічної діяльності більшою мірою застосовуються завдання з обробки великої кількості інфрормації (табл. 1).

IKT активно інтегруються у сфреру науки як невід'ємні технічні складові для детального аналізу сучасних процесів та подій. Завдяки IKT відкриваються нові галузі в науці та техніці, з'являється вільний доступ до інфрормації та масивів даних, з якими можна взаємодіяти 
Таблиця 1

Кількість підприємств, які мали фахівців у секторі ІКТ з розподілом за середньою кількістю працівників у 2017-2019 рр.

\begin{tabular}{|l|c|c|c|}
\hline \multicolumn{1}{|c|}{ Вид економічної діяльності } & \multicolumn{3}{|c|}{ Роки } \\
\cline { 2 - 4 } & $\mathbf{2 0 1 7}$ & $\mathbf{2 0 1 8}$ & $\mathbf{2 0 1 9}$ \\
\hline Переробна промисловість & 2627 & 2732 & 2699 \\
\hline $\begin{array}{l}\text { Постачання електроенергії, газу, пари } \\
\text { та кондиційованого повітря }\end{array}$ & 238 & 251 & 241 \\
\hline $\begin{array}{l}\text { Водопостачання; каналізація, поводження } \\
\text { 3 відходами }\end{array}$ & 197 & 209 & 203 \\
\hline Будівництво & 590 & 608 & 622 \\
\hline $\begin{array}{l}\text { Оптова та роздрібна торгівля; ремонт } \\
\text { автотранспортних засобів і мотоциклів }\end{array}$ & 2871 & 2918 & 2938 \\
\hline $\begin{array}{l}\text { Транспорт, складське господарство, поштова } \\
\text { та кур`єрська діяльність }\end{array}$ & 653 & 668 & 676 \\
\hline Тимчасове розміщування й організація харчування & 220 & 226 & 222 \\
\hline Інформація та телекомунікації & 1172 & 1274 & 1282 \\
\hline Операції з нерухомим майном & 543 & 546 & 546 \\
\hline Профресійна, наукова та технічна діяльність & 927 & 954 & 936 \\
\hline $\begin{array}{l}\text { Діяльність у сорері адміністративного } \\
\text { та допоміжного обслуговування }\end{array}$ & 594 & 555 & 559 \\
\hline
\end{tabular}

Джерело: побудовано на основі [2]

(передавати, обробляти, надсилати в інші країни). В свою чергу розвиток даного сектору сприяє не тільки технологічному поступу країни, але й економічному зростанню.

Роль інтеграції ІКТ в освітню сореру визначається наступними аспектами:

- можливості для зміни системи освіти;

- раціональне спрямування політичних програм та їх швидка імплементація у сорері освіти;

- розширення спектру можливостей як для бізнес-структур, так і для академічної спільноти в напрямку покращення підходів до навчання молодого покоління.

Розвиток IKT $€$ одним із стратегічних напрямків модернізації економіки. Розвиток нових технологій та інноваційних послуг, зростання інфрорматизації та технологічної освіченості суспільства, підвищення якості та зручності зв'язку, поява соціальних електронних порталів, доступність багатьох фрорм мультимедійного контенту на тлі зниження інтернет тарифрів і собівартості IT послуг має сприяти підвищенню продуктивності праці, стимулювати створення нових бізнесів і робочих місць і в цілому покращувати соціальну сферу i якість життя населення $[1$, с. 50$]$.

Сучасні тенденції в інвестуванні дають найменш розвиненим країнам можливості для перетворення їхніх слабких економік на високотехнологічні, тобто на ті, що спеціалізуються на продукції з високою доданою вар- тістю, і які можуть конкурувати з передовими економіками на світовому ринку. Звернемо увагу на те, що інформаційні інновації сприяли глобалізації через розбудову інфрраструктури для встановлення транссвітових зв'язків. Прогрес, що відображається у секторі IKT $€$ однією з рушійних сил глобалізації.

у 2010-2019 рр. капітальні інвестиції у комп'ютерне програмування та надання інших інформаційних послуг має тенденцію до збільшення, це можна пояснити тим, що ІКТ активно впроваджуються у бізнес, тим самим покращують продуктивність праці робітників (рис. 1).

Роль впровадження IKT у сореру бізнесу характеризується наступними аспектами:

- спрощення значної кількості бізнес-процесів та збільшення мобільності,

- сприяння дистанційному доступу до продуктивних систем (ERP), пришвидшення та спрощення комунікації в організаціях та за їх межами;

- систематизація більшості складних процесів на підприємствах за допомогою впровадження CRM систем, електронних таблиць та цифррового документообігу.

Додатково сектор IKT демонструє можливість працювати на нових ринках дистанційних послуг, таких як: медицина, освіта, юридична сорера, ссрера розваг, охорона та безпека. На базі ІКТ виникають нові фрормати взаємодії бізнесу із клієнтами. Ці та інші фрактори, без- 


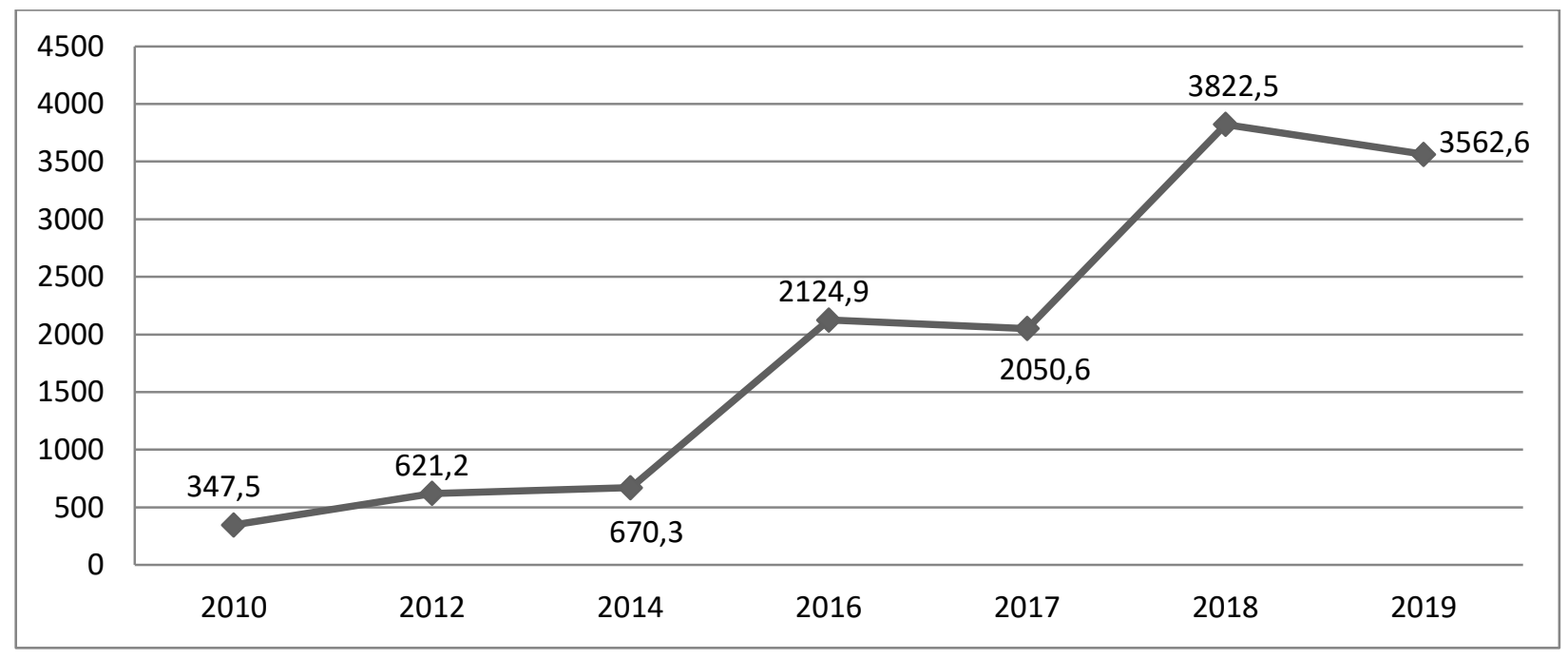

Рис. 1. Капітальні інвестиції у комп'ютерне програмування та надання інших інформаційних послуг (млн. грн.)

Джерело: побудовано на основі [2]

умовно збільшують можливості, динаміку та есрективність бізнесу.

Науковець Н.І. Тарасова виокремила такі підходи до класифрікації національного ринку IKT [6, c. 48]:

- інорраструктура - послуги 3 передачі інфрормації (перехід від аналогових методів передачі інформації до системи комунікацій, що поєднує цифрові фріксовані та мобільні мережі зв'язку);

-виробництвоапаратнихпристроїв-виробництво засобів введення, зберігання аналізу та передачі інфрормації;

- випуск програмних продуктів та інтеграційні рішення - написання набору інструкцій для апаратних та/або інсрраструктурних об'єктів, 3 якими останні виконують певні визначені дії для досягнення необхідних користувачу результатів.

Важлива роль IKT полягає у наданні можливості людям, урядам та організаціям перетворити інсрормацію на знання, які $€$ потужним рушієм змін в національній економіці. Крім того, ІКТ сприяють стійкому довгостроковому зростанню виробництва за допомогою ретельно розроблених автоматизованих систем та використання програмного забезпечення. Згідно з цим інвестування в сучасну IKT-індрраструктуру буде сприяти стійкому економічному зростанню, високим стандартам життя та розумному управлінню природними ресурсами.

Виділяючи питання регулювання ринку IKT за даними Global ICT Regulatory Outlook 2018 виділено наступні світові тренди [8]:
- найвищий рівень - четверте покоління складається 3 успішних, які просунулися на хвилі Четвертої промислової революції, відстояли свої позиції, щоб захистити споживачів, інтереси, відкрили ринки і просувають інвестиції для досягнення соціальних і економічних цілей;

- середній рівень - третє покоління - просувається вперед, розвиваючи межі і ринки в сторону більш адаптивних, конкурентних режимів регулювання;

- група нижнього рівня - регулятори першого і другого покоління - втрачає позиції і скорочується в кількості. Країни не цінують і не отримують вигоду через недостатній розвитку їх ринкової структури та інструментів регулювання.

Україна займає 78 позицію із 96 країн [9], що характеризує як низький рівень розвитку регулювання досліджуваної сорери. Прогрес і вдосконалення регулювання IКT $€$ потужною заявою про прагнення до розвитку, і жодна країна не може дозволити собі втратити значну можливість, яку представляє все більш відкритий і динамічний ринок.

В сучасних умовах конкуренції на світовому ринку перевагу в залученні інвестицій та розвитку стартапів мають ті країни, які спеціалізуються на розробці високотехнологічної продукції та сприяють розвитку інновацій. Багато європейських країн розглядають розвиток і використання інфрормаційно-комунікаційних технологій в економіці та суспільстві як ключовий компонент національної стратегії задля покращення рівня життя, зростання 
рівня знань та посилення власної міжнародної конкурентоспроможності.

Досліджуючи особливості становлення інформаційної економіки в Україні І.П. Малик виділив такі як поява нових виробничих сил, впровадження інформаційних технологій у виробництво, зміна характеру праці та структурні зміни на макро- та мікроекономічному рівнях [4, с. 28].

Розвиток ІКТ сприяє виникненню багатьох нових напрямків в бізнесі та економіці, одним 3 таких є електронна комерція (он-лайн продаж). У багатьох країнах світу торгові он-лайн майданчики переважають над реальними (офр-лайн) торговими майданчиками. У зв'язку 3 глобалізацією та розвитком IKT кордони значно розширилися, кожного дня відкриваються все нові можливості для бізнесу і економіки загалом. Розширюються ринки збуту, виникають абсолютно нові товари та послуги (частина 3 яких надається онлайн), також важливим елементом виступає те, що часто послуги, які можна отримати онлайн, нічим не відрізняються, або й навпаки значно перева- жають, як в якості, так і в ціні. Завдяки зростанню частки IКT в банківській сфрері, населення може здійснювати миттєві банківські операції з допомогою електронних пристроїв, відслідковувати SWIFT перекази, працювати з фондами і навіть займатися трейдингом.

Висновки. Встановлено, що сектор IKT $€$ динамічним і таким, що інтегрується у різні види економічної діяльності. В національній економіці розвиток цього сектору повинен бути спрямованим на розвиток стартапів та фрормування сприятливого середовища для їх створення та впровадження. Також повинні забезпечуватися умови для поліпшення конкурентоспроможності товарів і послуг через активізацію розвитку секторі IКT. Важливими для цього стають формування національної стратегії підтримки розвитку сектору IKT, збалансування міжнародної та внутрішньої політики, створення сприятливої економічного середовища в галузі інфрорматизації, фрормування інституцій для покращення якісних характеристик національних товарів, стимулювання інвестицій у людський капітал.

\section{СПИСОК ВИКОРИСТАНИХ ДЖЕРЕЛ:}

1. Безугла К.О. Інформаційно-комунікаційні технології як фрактор інноваційного розвитку економіки. Економіко-математичне моделювання соціально-економічних систем. 2013. № 18. С. 42-55.

2. Державна служба статистики. Інсрормаційне суспільство. URL: http://www.ukrstat.gov.ua/ (дата звернення: 24.04.2021).

3. Карапиш С.П. Упровадження інформаційно-комунікаційних технологій у систему управління загальної середньої освіти. Публічне управління та митне адміністрування. 2020. № 3. С. 38-42.

4. Малик І.П. Тенденції розвитку інсрормаційної економіки в Україні. Вісник Східноєвропейського університету економіки і менеджменту. Сер. : Економіка і менеджмент. 2013. № 1. С. 25-34.

5. Скиба І.П., Орденов С.С., Ченбай Н.А. Феномен інформаційно-комунікаційних технологій. Філософрські обрії: наук.-теорет. журн. 2019. № 42. С. 62-67.

6. Тарасова К.І. Ринок інформаційно-комунікаційних технологій у системі національного господарства. Інфраструктура ринку. 2018. № 16. С. 46-51.

7. Уніят Л.М. Інфрормаційно-комунікаційні технології як фрактор інноваційного розвитку агропромислових підприємств. Інноваційна економіка. 2019. № 7-8. С. 152-159.

8. Global ICT Regulatory Outlook 2018. URL: https://www.itu.int/pub/D-PREF-BB.REG_OUT01-2018 (дата звернення: 24.04.2021).

9. Global ICT Regulatory Outlook 2020.URL: https://www.itu.int/pub/D-PREF-BB.REG_OUT01-2018 (дата звернення: 24.04.2021).

\section{REFERENCES:}

1. Bezuhla, K. (2013). Informatsiyno-komunikatsiyni tekhnolohiyi yak faktor innovatsiynoho rozvytku ekonomiky. Ekonomiko-matematychne modelyuvannya sotsial'no-ekonomichnykh system, 18, 42-55. (in Ukrainian)

2. Derzhavna sluzhba statystyky. Informatsiyne suspil'stvo. URL: http://www.ukrstat.gov.ua/ (accessed 24 April 2021)

3. Karapysh, S. (2020). Uprovadzhennya informatsiyno-komunikatsiynykh tekhnolohiy u systemu upravlinnya zahal'noyi seredn'oyi osvity . Publichne upravlinnya ta mytne administruvannya, 3, 8-42. (in Ukrainian)

4. Malyk, I. (2013). Tendentsiyi rozvytku informatsiynoyi ekonomiky v Ukrayini. Visnyk Skhidnoyevropeys'koho universytetu ekonomiky i menedzhmentu. Ser.: Ekonomika i menedzhment, 1, 25-34. (in Ukrainian) 
5. Skyba, I., Ordenov, S., Chenbay, N. (2019). Fenomen informatsiyno-komunikatsiynykh tekhnolohiy. Filosofs'ki obriyi: nauk.-teoret. zhurn, 42, 62-67. (in Ukrainian)

6. Tarasova, K. (2018). Rynok informatsiyno-komunikatsiynykh tekhnolohiy u systemi natsional'noho hospodarstva. Infrastruktura rynku, 16, 46-51. (in Ukrainian)

7. Uniyat, L. (2019). Informatsiyno-komunikatsiyni tekhnolohiyi yak faktor innovatsiynoho rozvytku ahropromyslovykh pidpryyemstv. Innovatsiyna ekonomika, 7-8, 152-159. (in Ukrainian)

8. Global ICT Regulatory Outlook 2018. URL: https://www.itu.int/pub/D-PREF-BB.REG_OUT01-2018 (accessed 24 April 2021).

9. Global ICT Regulatory Outlook 2020. URL: https://www.itu.int/pub/D-PREF-BB.REG_OUT01-2018 (accessed 24 April 2021). 